\title{
Pengaruh Work from Home Internship di Kantor Akuntan Publik bagi Soft Skill Mahasiswa
}

\author{
Ketut Redita ${ }^{1,}{ }^{*}$, Icha Hafsari ${ }^{1}$, Luh Putri Tersiani ${ }^{1}$, Retno Yuliati ${ }^{1}$ \\ ${ }^{1}$ Faculty of Buiness and Economics; Universitas Prasetiya Mulya; BSD City Kavling Edutown \\ I.1, Jl. BSD Raya Utama, BSD City, Kec. Pagedangan, Tangerang, Banten; TIp. (021) \\ 30450500; e-mail: ketutredita87@gmail.com, ichahafsari13@gmail.com, \\ putritersiani10@gmail.com, retno.yuliati@pmbs.ac.id \\ * Korespondensi: e-mail: ketutredita87@gmail.com
}

Submitted: 11/08/2021; Revised: 08/09/2021; Accepted: 10/09/2021; Published: 30/09/2021

\begin{abstract}
Previous research has proven that the internship program could develop students' soft skills that they didn't get in college. However, there is no further research that examines students' soft skills if WFH carries out the internship. This study explores the soft skills of accounting students while they are doing WFH internships due to the Covid-19 Pandemic. This research is descriptive qualitative research. The data collection was conducted by interviewing 12 accounting students who had completed the internship program at Big 4 and Non-Big 4 Public Accountant Firm for three months. This study found that WFH Internship helps develop soft skills such as flexibility and adaptation, critical thinking, problem-solving, time management, responsibility, and initiative. However, communication, collaboration, and teamwork are less honed due to the lack of direct interaction on the WFH system. The limitation of this research is the selection of informants who all come from accounting students at Universitas Prasetiya Mulya. This study provides information and insight to various parties related to how the Work from Home (WFH) system that is also applied to internal employees continues to influence internal soft skills, especially accounting interns.
\end{abstract}

Keywords: Covid-19 Pandemic, Internship, Soft Skill, Work From Home (WFH)

\begin{abstract}
Abstrak
Penelitian sebelumnya membuktikan bahwa program magang mampu mengembangkan soft skill mahasiswa yang tidak didapatkan di bangku kuliah. Namun belum ada penelitian lebih lanjut yang meneliti perkembangan soft skill mahasiswa jika magang yang dilakukan secara WFH. Tujuan penelitian ini adalah untuk melihat kemampuan soft skill apa saja yang terasah dan berkembang selama mahasiswa akuntansi melakukan magang secara WFH dikarenakan Pandemi Covid-19. Penelitian ini merupakan penelitian kualitatif deskriptif yang pengumpulan datanya dilakukan dengan metode wawancara kepada 12 mahasiswa akuntansi yang telah menyelesaikan program magang di KAP Big 4 dan Non-Big 4 selama tiga bulan. Penelitian ini menemukan bahwa WFH Internship membantu mengembangkan soft skill mahasiswa berupa fleksibilitas dan adaptasi, kemampuan berpikir kritis, kemampuan menyelesaikan masalah, manajemen waktu, tanggung jawab, dan inisiatif. Sedangkan untuk komunikasi, kolaborasi dan kerja tim kurang terasah karena minimnya interaksi secara langsung pada sistem WFH. Keterbatasan penelitian ini ada pada pemilihan informan yang semuanya berasal dari mahasiswa akuntansi Universitas Prasetiya Mulya. Penelitian ini memberikan informasi dan wawasan kepada berbagai pihak terkait bagaimana agar sistem Work from Home (WFH) yang diberlakukan juga untuk para intern tetap memberikan pengaruh yang dapat meningkatkan soft skill intern khususnya para intern dari akuntansi.
\end{abstract}

Kata kunci: Pandemic Covid-19, Internship, Soft Skill, Work From Home (WFH) 


\section{Pendahuluan}

Pandemi yang disebabkan oleh virus corona pertama kali dilaporkan secara resmi Pemerintah China kepada World Health Organization (WHO) pada tanggal 31 Desember 2019 (Arnani, 2021). Sejak ditemukan virus ini terus dan cepat tersebar di seluruh negara belahan dunia termasuk Indonesia. Berbagai aspek kehidupan ikut terdampak karena virus corona ini yaitu bidang kesehatan, ekonomi, bahkan pendidikan juga ikut kena imbasnya. Akibat pandemi ini membuat orang harus bekerja dari rumah dan siswa pun harus belajar dari rumah dengan metode Pelajaran Jarak Jauh.

Istilah Work from Home (WFH) mulai dikenal, bahkan di Indonesia kementerian yang ada menerapkan juga metode bekerja dari rumah ini dengan menerbitkan surat edaran tentang tata cara pelaksanaan bekerja dari rumah misalnya Surat Edaran Menteri Komunikasi dan Informatika Nomor 4 Tahun 2020 tentang Protokol Pelaksanaan Work from Office dan Work from Home (WFH)/Flexible Working Space (FWS) dalam Tatanan Normal Baru Bagi Pegawai di Lingkungan Kementerian Komunikasi dan Informatika (Menkominfo, 2020). Semua lembaga dan juga perusahaan diharapkan bisa melakukan WFH untuk memutus penyebaran Covid-19.

Imbas bagi dunia pendidikan dengan adanya kebijakan ini adalah beberapa program dari sekolah maupun perguruan tinggi ikut berdampak seperti program magang yang dilakukan oleh setiap mahasiswa ketika sudah memasuki semester yang telah ditentukan oleh universitas untuk melakukan magang. Kondisi yang mengharuskan WFH membuat mahasiswa melakukan magang secara WFH. Semua tugas yang diberikan supervisor harus dikerjakan dari rumah. Terkhusus mahasiswa jurusan akuntansi yang magang di Kantor Akuntan Publik (KAP) harus melakukan tugas-tugas audit secara online. Tentu ini menjadi tantangan tersendiri saat mereka harus mengaudit laporan keuangan tanpa bertemu secara langsung dengan timnya dan juga klien yang laporan keuangannya sedang mereka audit.

Berdasarkan pemaparan di atas, kami tertarik meneliti lebih lanjut mengenai bagaimana pengaruh WFH Internship di Kantor Akuntan Publik terhadap soft skill mahasiswa. Maka dari itu, kami membuat karya tulis yang berjudul "Work from Home Internship di Kantor Akuntan Publik: Bagaimana Pengaruhnya bagi Soft skill Mahasiswa?". Adapun tujuan dari penelitian ini adalah untuk menganalisis pengaruh Accounting WFH Internship terhadap peningkatan soft skill mahasiswa.

\subsection{Accounting Internship}

Program magang (internship) merupakan aktivitas yang dilakukan di luar perguruan tinggi untuk mengembangkan keterampilan yang dimiliki mahasiswa. Menurut (Arsilawanti, 2020) manfaat dari magang itu sendiri yaitu dapat menambah wawasan, pengetahuan, serta pengalaman dalam dunia kerja, sehingga pada akhirnya mahasiswa menjadi terbiasa dengan dunia kerja yang sebenarnya. Beberapa penelitian pun sudah membuktikan bahwa dengan melakukan kegiatan magang, dapat meningkatkan kompetensi yang dimiliki oleh peserta yang sedang mengikuti program magang (Lutfia \& Rahadi, 2020). Dalam mempersiapkan calon akuntan yang handal dan berkompeten, tentunya mahasiswa perlu dibekali pendidikan dan 
pelatihan akuntansi, salah satunya dengan program magang. Pada suatu penelitian menunjukkan dari 783 profesional akuntansi dan pendidik ditunjukkan bahwa magang merupakan aktivitas terbaik di luar kelas (Tataman \& Cummings, 2007).

Beberapa instansi atau perusahaan yang dapat menjadi pilihan bagi mahasiswa akuntansi yaitu lembaga pemerintahan, dunia bisnis, organisasi lainnya, serta perusahaan yang memberikan jasa auditing seperti Kantor Akuntan Publik (KAP). Dalam Peraturan Menteri Keuangan Republik Indonesia Nomor 154/PMK.01/2017 disebutkan Kantor Akuntan Publik yang selanjutnya disingkat KAP adalah badan usaha yang didirikan berdasarkan ketentuan peraturan perundang-undangan dan mendapatkan izin usaha berdasarkan Undang-Undang Nomor 5 Tahun 2011 tentang Akuntan Publik (Peraturan Menteri Keuangan, 2017). Mahasiswa yang memiliki orientasi karir ke bagian auditing, mayoritas memilih KAP sebagai tempat magang. Menurut (Nugraha, 2017), para intern di KAP tidak hanya mendapatkan ilmu dan pengalaman di bidang akademik saja, namun juga mendapatkan ilmu di bidang non-akademik.

\subsection{WFH Internship}

Di tengah masa pandemi covid-19 ini memaksa hampir seluruh perusahaan memberlakukan work from home (WFH). (Wong et al., 2020) berpendapat bahwa beberapa mahasiswa pergi ke kantor setiap hari, sementara beberapa bekerja sepenuhnya dari rumah dan beberapa lainnya merupakan gabungan dari dua metode ini. Ini pertama kalinya magang dilakukan secara WFH sehingga keberhasilannya tidak dapat dipastikan. WFH adalah salah satu bentuk pengaturan kerja jarak jauh dimana karyawan bekerja lingkungan rumah mereka dan tidak perlu melakukan perjalanan ke tempat kerja (International Labour Organization, 2020). Masalah yang akan segera terjadi untuk program magang WFH adalah komunikasi (Wong et al., 2020).

Literatur terdahulu menggambarkan bahwa komunikasi online cenderung lebih cocok untuk yang sudah memiliki hubungan interpersonal sebelumnya di tempat kerja sebelum mereka bekerja di rumah (Choudhury et al., 2019). Penelitian menemukan bahwa orang yang bekerja dari rumah tidak hanya mengalami penurunan tingkat komunikasi, tetapi juga harus berinteraksi dengan orang-orang secara jarak jauh dengan tingkat kecenderungan yang lebih rendah dibanding interaksi tatap muka (Cowgill et al., 2009).

\subsection{Soft Skill}

Keterampilan yang dimiliki oleh manusia yang sering dibahas dan dijadikan rujukan dalam penerimaan karyawan baru dalam suatu perusahaan adalah soft skill. Para eksekutif perusahaan mempertimbangkan bahwa soft skill merupakan atribut yang sangat penting yang harus dimiliki oleh pelamar kerja (Robles, 2012).

Soft Skill merupakan skill yang menunjang kesuksesan seseorang dalam berkarir. Seperti hasil penelitian yang dilakukan oleh oleh Harvard University, Carnegie Foundation dan Stanford Research Center, Amerika Serikat mengatakan bahwa "Soft skill bertanggung jawab sebesar $85 \%$ bagi kesuksesan karir seseorang, sementara hanya $15 \%$ disematkan kepada hard skill'. Hal ini dikuatkan oleh kajian yang dilakukan Depdiknas RI pada tahun 2009, yang 
menyatakan bahwa "Kesuksesan seseorang dalam pendidikan, 85\% ditentukan oleh Soft Skill (Muhmin, 2018).

Soft skill setiap orang bisa dilihat seperti di dalam 21st century skills, 2014 yaitu komunikasi yang terampil dan nyaman, kolaborasi dan kerja tim, kemampuan berpikir kritis, kemampuan menyelesaikan masalah, tanggung jawab, pengambilan keputusan, fleksibilitas dan kemampuan beradaptasi, manajemen waktu, inisiatif dan pengarahan diri sendiri, kompetensi sosial dan kewarganegaraan, kewirausahaan, dan sebagainya (Devedzic et al., 2018).

\subsection{Pengaruh Magang terhadap Soft Skill}

Berbagai penelitian telah dilakukan untuk melihat pengaruh magang terhadap soft skill peserta magang dan secara umum magang memang dianggap mampu meningkatkan soft skill. Soft skills tersebut yang dimaksud antara lain seperti kemampuan berkomunikasi dengan baik di lingkungan sekitar, kemampuan beradaptasi, kemampuan mengelola kerja tim, kemampuan bersosialisasi, dan ketelitian dalam bekerja (Lutfia \& Rahadi, 2020). Secara umum magang berdampak pada pengembangan keterampilan (Mabeba, 2019). Sebuah studi juga dilakukan oleh (Washor, 2015) mengenai pengaruh magang terhadap soft skill peserta magang yang hasilnya adalah magang terbukti meningkatkan soft skill. Dimana ketika magang para mahasiswa dapat berlatih berkomunikasi efektif, bekerja sebagai anggota tim, mengambil inisiatif, dan berpikir analitis tentang masalah yang dihadapi industri.

\section{Metode Penelitian}

Penelitian ini adalah kualitatif deskriptif yang menggambarkan dan menjelaskan bagaimana Accounting WFH Internship akibat fenomena pandemi berpengaruh terhadap soft skill intern. Penelitian ini dilakukan mulai tanggal 15 Maret s.d. 5 April 2021. Peneliti melakukan penelitian dari rumah masing-masing melalui media Zoom Meeting. Subjek penelitian ini adalah Mahasiswa Universitas Prasetiya Mulya yang telah melakukan program WFH Internship selama 3 bulan (Januari - Maret 2021) di Kantor Akuntan Publik, baik KAP Big 4 maupun Non-Big 4. Sebanyak 12 mahasiswa di-interview untuk mengetahui bagaimana pengaruh WFH Internship terhadap perkembangan soft skill mereka.

Dalam penelitian ini, peneliti melakukan wawancara terstruktur. Wawancara yang kami lakukan dengan menggunakan Zoom Meeting pada hari Sabtu, 27 Maret 2021 dan Minggu, 28 Maret 2021. Kami bertanya langsung kepada mahasiswa Universitas Prasetiya Mulya yang melakukan Accounting WFH Internship di Kantor Akuntan Publik. Wawancara dilakukan 1 sampai 2 jam untuk setiap peserta. Dalam penelitian ini kami juga mengumpulkan data dari jurnal dan buku yang berkaitan dengan magang offline dan online, soft skill, dan pengaruh magang terhadap peningkatan soft skill peserta magang.

Instrumen penelitian yang digunakan peneliti adalah pedoman wawancara yang berisi daftar pertanyaan yang akan ditanyakan kepada mahasiswa yang melakukan WFH Internship di 
Kantor Akuntan Publik. Berikut merupakan daftar pertanyaan wawancara yang kami tanyakan kepada para informan.

Tabel 1. Daftar Pertanyaan

\begin{tabular}{|c|c|}
\hline No. & Pertanyaan \\
\hline 1. & Perkenalan diri (nama, jurusan dan angkatan, tempat magang, divisi) \\
\hline 2. & $\begin{array}{l}\text { Informasi singkat terkait tempat magang, periode magang, job description, serta tugas sehari-hari } \\
\text { di divisi yang diambil }\end{array}$ \\
\hline 3. & Pelaksanaan magang di KAP, apakah secara WFH, WFO, atau mix \\
\hline 4. & Kesan serta suka duka magang di KAP, khususnya saat dilaksanakan secara WFH \\
\hline 5. & Perubahan yang dirasakan ketika shifting dari offline internship ke online internship \\
\hline 6. & $\begin{array}{l}\text { Sistem pemberian tugas, penyampaian materi serta pengawasan dari supervisor terhadap } \\
\text { mahasiswa magang }\end{array}$ \\
\hline 7. & Kelebihan dan kekurangan magang online \\
\hline 8. & $\begin{array}{l}\text { Proses komunikasi mahasiswa baik dengan perusahaan maupun rekan intern yang lain, termasuk } \\
\text { kendala yang dialami berkaitan dengan proses komunikasi }\end{array}$ \\
\hline 9. & Pengalaman unik yang dialami ketika komunikasi secara online \\
\hline 10. & $\begin{array}{l}\text { Tugas yang biasanya diberikan saat mengerjakan projek serta penentuan tenggat waktu } \\
\text { pengumpulan }\end{array}$ \\
\hline 11. & $\begin{array}{l}\text { Time management atau cara memanajemen waktu saat magang, termasuk pengaturan waktu } \\
\text { pengumpulan tugas yang diberikan serta preferensi informan terkait manajemen waktu baik saat } \\
\text { magang WFO maupun WFH }\end{array}$ \\
\hline 12. & Tanggapan yang diberikan perusahaan apabila terjadi keterlambatan pengumpulan tugas \\
\hline 13. & Kegiatan yang dilakukan mahasiswa ketika pekerjaan yang diberikan supervisor sudah selesai \\
\hline 14. & $\begin{array}{l}\text { Sistem pembagian tugas di masing-masing tim serta cara berkolaborasi dan koordinasi dalam } \\
\text { menyelesaikan tugas selama magang WFH }\end{array}$ \\
\hline 15. & $\begin{array}{l}\text { Kendala yang dihadapi oleh mahasiswa magang serta tindakan yang dilakukan untuk } \\
\text { menyelesaikan masalah tersebut }\end{array}$ \\
\hline 16. & Kesempatan untuk mengajukan ide atau pemikiran kepada senior \\
\hline 17. & $\begin{array}{l}\text { Tingkat kepuasan dan ekspektasi mahasiswa terhadap experience yang didapatkan ketika } \\
\text { magang }\end{array}$ \\
\hline 18. & Hal yang didapatkan dalam dunia magang namun tidak didapatkan ketika kuliah \\
\hline 19. & Minat dan kesiapan mahasiswa untuk melanjutkan karir di Kantor Akuntan Publik (KAP) \\
\hline 20. & $\begin{array}{l}\text { Saran dan pengembangan kepada KAP, universitas, tenaga pendidik, dan pihak lain yang } \\
\text { bersangkutan }\end{array}$ \\
\hline 21. & Pesan untuk mahasiswa yang ingin melakukan internship di Kantor Akuntan Publik \\
\hline
\end{tabular}

Adapun metode analisis data dalam penelitian ini adalah metode kualitatif dimana data yang dianalisis berupa teks yang berisi hasil wawancara yang telah peneliti lakukan kepada mahasiswa yang melakukan WFH Internship di Kantor Akuntan Publik. Hasil wawancara ini kemudian dikelompokan menjadi beberapa kategori untuk melihat pengaruhnya terhadap soft skill. Dalam penelitian ini, peneliti menganalisis soft skill fleksibilitas dan adaptasi, komunikasi, kolaborasi dan kerja tim, kemampuan berpikir kritis, kemampuan menyelesaikan masalah, manajemen waktu, tanggung jawab, dan inisiatif.

\section{Hasil dan Pembahasan}

Dalam penelitian ini, mahasiswa yang diinterview terdiri dari mahasiswa yang melakukan magang di KAP Big 4 dan Non-Big 4. Adapun persebaran informan di KAP disajikan pada Tabel 2. 
Tabel 2. Persebaran Informan

\begin{tabular}{|c|c|c|c|c|}
\hline No. & Nama Informan & Jenis Kelamin & KAP Big Four & $\begin{array}{c}\text { KAP Non-Big } \\
\text { Four }\end{array}$ \\
\hline 1. & Informan A & Perempuan & $\checkmark$ & \\
\hline 2. & Informan B & Perempuan & $\checkmark$ & \\
\hline 3. & Informan C & Laki-Laki & $\checkmark$ & \\
\hline 4. & Informan D & Perempuan & & $\checkmark$ \\
\hline 5. & Informan E & Perempuan & $\checkmark$ & \\
\hline 6. & Informan F & Perempuan & $\nabla$ & \\
\hline 7. & Informan G & Perempuan & $\checkmark$ & \\
\hline 8. & Informan $\mathrm{H}$ & Laki-Laki & $\checkmark$ & \\
\hline 9. & Informan I & Perempuan & & $\checkmark$ \\
\hline 10. & Informan J & Laki-Laki & & $\checkmark$ \\
\hline 11. & Informan K & Perempuan & $\checkmark$ & \\
\hline 12. & Informan L & Perempuan & $\checkmark$ & \\
\hline
\end{tabular}

Sumber: Hasil Penelitian (2021)

Kemampuan soft skill yang sering muncul selama interview adalah fleksibilitas dan adaptasi, komunikasi, kolaborasi dan kerja tim, kemampuan berpikir kritis, kemampuan menyelesaikan masalah, manajemen waktu, tanggung jawab, dan inisiatif.

\subsection{Fleksibilitas dan Adaptasi}

Fleksibilitas dan adaptasi adalah kemauan untuk berubah dan menerima hal baru (Dabke, 2015). Hasil wawancara menunjukkan bahwa hampir semua informan menunjukkan kemampuan fleksibilitas dan adaptasi yang baik walaupun magang dilakukan secara WFH.

"... awalnya kesel di depan laptop terus tapi lama-kelamaan jadi terbiasa..." (Informan B)

Kemampuan adaptasi tidak hanya karena perubahan sistem magang yang WFH tetapi juga dalam menyesuaikan cara dan pembagian tugas yang dinamis.

“... seminggu sekali bakal pindah klien, sebenarnya capek tapi enaknya bisa dapet banyak pembelajaran. Jadi kalau udah banyak klien yang dihadapi, buat kedepannya ngadepin klien lain udah tau gimana caranya..." (Informan F)

Pernyataan di atas menunjukkan bahwa WFH Internship mampu mengembangkan fleksibilitas dan kemampuan beradaptasi mahasiswa terhadap berbagai perubahan dan dinamika dalam lingkungan kerja. Bahkan mahasiswa magang diberikan kesempatan untuk berpindah klien ketika projek sebelumnya telah selesai. Hal ini secara tidak langsung akan mendorong mahasiswa untuk menyesuaikan diri dengan budaya kerja tim yang baru dan akan menstimulasi kemampuan beradaptasi.

\subsection{Komunikasi}

Kemampuan berkomunikasi adalah salah satu soft skill yang tidak hanya menunjukkan kemampuan dalam berbicara, tetapi juga menunjukkan kemampuan menulis, mendengarkan, dan mempresentasikan sesuatu (Dabke, 2015). Informan dalam penelitian ini menceritakan berbagai pengalamannya dalam berkomunikasi. Sebagian besar informan menggambarkan bahwa komunikasi mereka terbatas karena sistem magang WFH menyebabkan minimnya interaksi secara tatap muka langsung. Komunikasi kepada senior yang dilakukan via chat 
ataupun google meeting sebagian besar hanya sebatas pekerjaan dan tugas. Komunikasi secara online ini tidak memberikan kesempatan kepada para intern untuk menjalin pertemanan baik dengan senior maupun rekan sesama intern.

Dalam hal komunikasi, sebagian informan sepakat bahwa komunikasi sedikit terhambat karena kurangnya human interaction, sebagaimana yang disampaikan oleh Informan F dan G.

“... walaupun ada mahasiswa lain dari luar universitas gak membuat kami jadi sering berinteraksi. Tugas pun terpusat kepada associate jadi berinteraksi dengan mahasiswa lain hanya karena urusan kerja. Namun, selain komunikasi dengan associate aku juga menghubungi pihak bank untuk melakukan validasi..." (Informan F)

“... komunikasi santai dengan associate dan associate juga terbuka tapi kalau kenalan sama mahasiswa universitas lain gak ada karena media buat bisa kenal sama mereka itu gak ada kecuali yg satu tim..." (Informan G)

Minimnya interaksi sosial secara langsung bukan satu-satunya hal yang menghambat kesempatan untuk mengembangkan komunikasi, namun media untuk berkomunikasi terbatas karena bahkan dengan google meeting mereka tidak saling on camera.

“...semua gmeet/zoom kayak gitu gak pernah sama sekali pakai video, aku seneng-seneng aja sih. Tapi paling kita judge orang dari suara mereka aja. Oo...dia kesannya (suaranya) kayak friendly banget jadi aku ngomongnya lebih enak. Oo...dia kesannya buru-buru, jadi aku harus lebih cepet-cepet ngerti..." (Informan D).

Salah satu informan berpendapat, minimnya interaksi membuat bekerja menjadi lebih efektif karena tidak perlu berbasa-basi. Respon positif informan atas komunikasi yang minim dimanfaatkan untuk bekerja lebih produktif.

“...tidak perlu banyak wasting time ngobrol sana-sini yang gak relevan..." (Informan H)

Namun tidak dipungkiri bahwa ada sebagian informan merasa kemampuan berkomunikasinya lebih terasah karena adanya kesempatan untuk berkomunikasi dengan pihak eksternal misalnya pihak bank untuk melakukan validasi dan pihak klien untuk mendapatkan data walaupun melalui telepon dan email.

“...pas awal-awal formal banget (berkomunikasi dengan klien), kayak template,

bikin kalimat sopan dan panjang banget. Harus basa-basi dulu dengan klien, pendekatan...." (Informan C).

Pernyataan diatas menunjukkan bahwa perkembangan soft skill dari sisi komunikasi selama magang dengan WFH terkait dengan sejauh apa interaksi sosial yang mereka lakukan dan kesempatan yang diberikan untuk berkomunikasi dengan banyak pihak.

\subsection{Kolaborasi dan Kerja Tim}

Kolaborasi dan kerja tim merujuk pada kerjasama, berhubungan baik dengan yang lain, agreeable, saling mendukung, saling membantu dan berkolaborasi (Dabke, 2015). Indikator dari 
kerja tim adalah menyelesaikan tugas tepat waktu, berpartisipasi secara aktif dalam tim, dan berkomitmen pada tugas yang sudah dibebankan (Cimatti, 2016). Para intern yang melakukan magang di KAP sudah menunjukkan kemampuan kolaborasi dan kerjasama tim terbukti dengan selalu menyelesaikan pekerjaan yang diberikan oleh senior dengan sebaik-baiknya. Namun, mereka sepakat bahwa mereka tidak punya kesempatan untuk mempraktikkan kerja tim seperti yang mereka harapkan. Hal ini dikarenakan tugas yang diberikan kepada para intern berbedabeda dan kurang memiliki keterkaitan satu sama lain, sehingga hampir seluruh tugas dikerjakan secara individu. Selain itu, intern tidak memiliki kesempatan untuk berkolaborasi secara penuh karena sistem magang yang WFH.

“.... sebenernya kalo offline itu kita kerja tim, cuma berhubung kita anak intern dan magangnya WFH, jadinya nggak dilibatkan secara langsung dalam kerja tim. Jadi kita ngerjain tugas yang dikasih itu secara mandiri...." (Informan E)

“... pekerjaan auditor (sebagai intern) kebanyakan sifatnya memang individualis, jadi tiap orang itu di-assign tugas yang berbeda dan kita fokus buat ngerjain tugas yang udah dikasih. Kalau ada yang nggak ngerti atau yang melibatkan diskusi itu baru ngerjain worksheet bareng associate dan disediakan meet kalo mau tanya-tanya..." (Informan G)

Namun peneliti menemukan adanya pendapat yang kontradiktif dari salah satu informan. la menyampaikan bahwa masih ada kemungkinan untuk melakukan kolaborasi, namun hanya sebatas membahas tugas yang kurang dimengerti dengan rekan intern.

“... cuma kalo ada tugas temen yang belum selesai kita tetap bantu, itupun kalau pekerjaan atau tugasnya memang sama, ya kita tetap kasih tau cara pengerjaan tugasnya kayak gimana, kemudian mereka ngelanjutin tugasnya sampai selesai. Intinya kita tetap saling sharing cara kalau ada kesulitan...." (Informan D)

\subsection{Kemampuan Berpikir Kritis}

Beberapa informan yang melaksanakan Accounting WFH Internship di Kantor Akuntan Publik terlatih untuk berpikir kritis (critical thinking). Hal ini dikarenakan mahasiswa selalu diberikan tugas dan proyek yang membutuhkan analisis.

“...Kalau excel nggak pernah diajarin rumus tapi short cut aja, jadi saya biasanya melihat pekerjaan yang telah diselesaikan mereka sebelumnya. Rumus apa yang mereka pakai buat ini, kenapa pakai rumus ini ya? ..." (Informan B)

“...Melatih saya buat mikir angka ini dari mana terus dianalisis gitu. Nah associate juga bantu buat ngarahin analisis ini..." (Informan G)

\subsection{Kemampuan Menyelesaikan Masalah}

Semua informan yang melaksanakan Accounting WFH Internship tidak pernah menemukan permasalahan dan kendala yang besar, karena mereka selalu diawasi dan dibantu oleh seniornya. Yang menjadi permasalahan, mahasiswa hanya dihadapkan pada permasalahan yang kecil, sehingga kemampuan problem solving tidak mampu berkembang secara maksimal. 
“...Pernah menemukan masalah, konfirmasi klien orang luar negeri, tahun lalu kan dikirim surat tapi sekarang by system online gitu. Kliennya merasa ribet dan kayak nggak bisa gitu gunain sistemnya jadi kita harus kontakin dia setiap hari kita harus jelasin pelan-pelan, sabar..." (Informan A)

Mahasiswa magang belum mempunyai kesempatan diberikan tugas-tugas yang signifikan. Tugas mahasiswa magang sebagai assurance berkisar pada vouching. Jika menemukan masalah/kesulitan mereka dapat langsung mengkomunikasikan dengan para senior. Sebagian besar informan menyatakan bahwa selama magang, senior di dalam tim berperan besar dalam mengarahkan dan memberikan petunjuk terkait tugas yang harus diselesaikan oleh intern. Mereka tidak ragu untuk bertanya bahkan untuk hal-hal yang sepele.

“...kebetulan aku dapet tim yang lumayan banget mau ngajarin, jadi aku ngerasa dibimbing banget...." (Informan H)

“.... filosofinya, lebih baik nanya daripada salah...." (Informan G)

Pernyataan di atas menunjukkan bahwa memang sifat alami magang adalah adanya mentorship untuk mendukung keberhasilan pengalaman magang mahasiswa. Hal ini belum mampu mengasah kemampuan para intern dalam penyelesaian masalah. Namun ini sesuai dengan proporsi tanggung jawab yang pantas dibebankan untuk anak magang sebagai jembatan antara bangku perkuliahan dengan dunia kerja.

\subsection{Manajemen Waktu}

Dalam hal manajemen waktu, para intern sepakat bahwa mereka mampu mengatur waktu dengan baik. Meskipun tidak pernah diberikan tenggat waktu, mahasiswa mampu menyelesaikan tugas yang diberikan bahkan sebelum diminta oleh senior.

".... tenggat waktu bukan dari senior tapi dari diri sendiri. Aku nggak suka menumpuk-numpuk pekerjaan. Karena pekerjaan baru akan datang lagi. Aku punya list tugas yang harus aku kerjakan terlebih dahulu. Intinya selesaikan pekerjaan secara efektif dan efisien..." (Informan A)

“... aku juga terkadang dikasih tugas banyak tapi aku selalu ngatur kira-kira bisa berapa lama pekerjaan ini selesai..." (Informan F)

"... biasanya aku submit hari itu juga tapi biasanya tanya dulu mau kapan dimintanya kalo pas banyak yg di handle..." (Informan I)

\subsection{Tanggung Jawab}

Tanggung jawab tercermin dari dapat diandalkan, disiplin diri, melakukan pekerjaan dengan baik, ingin melakukan dengan baik (Dabke, 2015). Para intern sangat bertanggung jawab terhadap tugas yang diberikan oleh senior kepada mereka dan menyelesaikannya tanpa diminta terdahulu oleh senior mereka.

“... tidak pernah melewati deadline, aku selalu menyelesaikan pekerjaan tepat waktu..." (Informan A)

“... kalo (disini) memang nggak ada sistem pengawasan secara langsung. Jadi intern kerja sesuai dengan kesadaran masing-masing. Tetap rajin update 
progress kerjanya sudah sampai mana walaupun nggak diminta langsung. Intinya sih tetap tanggung jawab dengan pekerjaan yang udah dikasih sih..." (Informan C)

Pernyataan di atas menunjukkan bahwa sebagai intern mereka merasa lebih mandiri dan profesional selama masa magang, karena mereka dapat menjaga jadwal kerja masingmasing.

\subsection{Inisiatif}

Para intern memiliki inisiatif yang tinggi, hal ini dicirikan dari mereka selalu menyelesaikan tugas tanpa diawasi oleh senior. Bahkan intern selalu bertanya kepada supervisor mengenai tugas yang bisa mereka bantu ketika pekerjaan sebelumnya telah diselesaikan.

“... baru bangun pagi aku selalu chat seniornya, apakah ada yang bisa dibantu kak? Kalau dijawab belum ada, aku nanya lagi ke senior yang lain apakah ada pekerjaan yang bisa aku bantu? ..." (Informan B)

".... kalau lagi kosong sih kadang main hape selama 15 menit sambil peregangan, tapi tetap biasanya aku selalu merhatiin chat dan berusaha bales chat dari senior at least 1 jam setelah di-chat. So, I always try to open my computer. Jadi kalo ada informasi atau apa aku bisa langsung tau..." (Informan E)

Berdasarkan pernyataan para informan dan analisis yang kami lakukan dapat dikatakan bahwa WFH Internship berpengaruh dan membantu mengembangkan soft skill intern seperti fleksibilitas dan adaptasi, kemampuan berpikir kritis, kemampuan menyelesaikan masalah, manajemen waktu, tanggung jawab, dan inisiatif. Sedangkan untuk komunikasi, kolaborasi dan kerja tim tidak terasah seperti yang mereka harapkan. Komunikasi yang dilakukan intern dan supervisor/seniornya hanya sebatas dalam hal yang berkaitan dengan pemberian tugas oleh senior/supervisor. Diluar itu komunikasi sangat jarang dilakukan. Selain itu, intern juga jarang mengerjakan pekerjaanya dengan cara kolaborasi atau kerja tim dikarenakan tugas yang diberikan berbeda-beda sehingga intern hanya bertanggung jawab untuk menyelesaikan pekerjaan yang supervisor/senior berikan.

\section{Kesimpulan}

Hasil penelitian ini menunjukkan bahwa WFH Internship berpengaruh dan membantu mengembangkan soft skill intern seperti fleksibilitas dan adaptasi, kemampuan berpikir kritis, kemampuan menyelesaikan masalah, manajemen waktu, tanggung jawab, dan inisiatif. Namun untuk komunikasi, kolaborasi dan kerja tim belum dapat memenuhi seperti yang diharapkan karena keterbatasan WFH. Karena work from home, komunikasi yang dilakukan sebatas menanyakan tugas yang bisa dibantu oleh intern, diluar itu sangat jarang berkomunikasi. Sedangkan untuk kolaborasi dan kerja tim yang belum seperti yang diharapkan dikarenakan tugas yang diberikan kepada para intern berbeda-beda dan kurang memiliki keterkaitan satu sama lain, sehingga hampir seluruh tugas dikerjakan secara individu. Hasil penelitian ini 
berimplikasi tidak hanya bagi universitas sebagai penyelenggara pendidikan, tetapi juga bagi KAP dan pemerintah. Bagi Universitas, khususnya penyelenggara pendidikan akuntansi, sebaiknya bekerja sama dengan KAP atau perusahaan-perusahaan lainnya untuk mendesain program magang WFH yang dapat melatih dan mengembangkan soft skill yang dimiliki mahasiswa sebagai peserta magang. Bagi KAP, lebih memberikan kesempatan dan kepercayaan kepada mahasiswa magang untuk berinteraksi dan berkomunikasi dengan pihak luar karena berdasarkan hasil penelitian ini, kesempatan berkomunikasi dengan klien dapat mengasah kemampuan berkomunikasi. Bagi Pemerintah, khususnya Kementerian Pendidikan dan Kebudayaan, hasil penelitian ini mengkonfirmasi pentingnya program magang seperti yang dicanangkan dalam program Merdeka Belajar. Keterbatasan penelitian ini adalah informan yang hanya dari Mahasiswa Universitas Prasetiya Mulya karena kesulitan mencari informan dari universitas lain. Penelitian selanjutnya sebaiknya memperkaya analisis dengan temuan dari informan yang berasal dari universitas yang berbeda-beda. Selain itu, peneliti kurang mengetahui informan jujur atau tidak karena ketika wawancara via zoom beberapa informan tidak menyalakan kamera sehingga peneliti tidak bisa melihat ekspresi informan.

\section{Daftar Pustaka}

Arnani, M. (KOMPAS). (2021). Timeline Wabah Virus Corona, Terdeteksi Pada Desember 2019 Hingga Jadi Pandemi Global. Kompas. https://www.kompas.com/tren/read/2020/03/12/113008565/timeline-wabah-virus-coronaterdeteksi-pada-desember-2019-hingga-jadi?page=all

Arsilawanti, S. P. (2020). Laporan Kuliah Kerja Magang (KKM) Sistem Informasi Akuntansi Penerimaan Kas pada Agen Pos Merdeka Jombang.

Choudhury, P., Larson, B. Z., \& Foroughi, C. (2019). Is It Time to Let Employees Work from Anywhere? Harvard Business Review. https://hbr.org/2019/08/is-it-time-to-let-employeeswork-from-anywhere

Cimatti, B. (2016). Definition, development, assessment of soft skills and their role for the quality of organizations and enterprises. International Journal for Quality Research, 10(1), 97130. https://doi.org/10.18421/IJQR10.01-05

Cowgill, B., Wolfers, J., \& Zitzewitz, E. (2009). Using Prediction Markets to Track Information Flows: Evidence from Google. 3-3. https://doi.org/10.1007/978-3-642-03821-1_2

Dabke, D. (2015). Soft Skills as a Predictor of Perceived Internship Effectiveness and Permanent Placement Opportunity. The IUP Journal of Soft Skills, 9(4), 26.

Devedzic, V., Tomic, B., Jovanovic, J., Kelly, M., Milikic, N., Dimitrijevic, S., Djuric, D., \& Sevarac, Z. (2018). Metrics for Students' Soft Skills. Applied Measurement in Education; Routledge. https://doi.org/10.1080/08957347.2018.1495212

International Labour Organization. (2020). An employers' Guide on Working from Home in Response to the Outbreak of COVID-19. In International Labour Organization. https://www.ilo.org/actemp/publications/WCMS_745024/lang--en/index.htm 
Lutfia, D. D., \& Rahadi, D. R. (2020). Analisis Internship Bagi Peningkatan Kompetensi Mahasiswa. Jurnal Ilmiah Manajemen Kesatuan, 8(3), 199-204. https://doi.org/10.37641/jimkes.v8i3.340

Mabeba, S. J. (2019). The Impact of Internship Programme on Skills Development in the South African Public Institutions : Are Internships Still Relevant ? July, 21-28.

Menkominfo. (2020). Protokol Pelaksanaan Work From Office (WFO) Dan Work From Home (WFH) / Flexible Working Space (FWS) Dalam Tatanan Normal Baru Bagi Pegawai Di Lingkungan Kementerian Komunikasi dan Informatika (p. 25).

Muhmin, A. H. (2018). Pentingnya Pengembangan Soft Skills Mahasiswa di Perguruan Tinggi Forum IImiah. Forum IImiah Volume 15 Nomor 2, 15, 330.

Nugraha, Y. A. (2017). Laporan Magang Kantor Akuntan Publik Mahsun Armand Nurgrahanto.

Peraturan Menteri Keuangan. (2017). Peraturan Menteri Keuangan Republik Indonesia Nomor tentang Jasa Akuntan Publik. 1-100.

Robles, M. M. (2012). Executive Perceptions of the Top 10 Soft Skills Needed in Today's Workplace. Business Communication Quarterly, 75(4), 453-465. https://doi.org/10.1177/1080569912460400

Tataman, W. S., \& Cummings, R. (2007). Accounting Internships : 5(12), 1-12.

Washor, K. S. (2015). Bridging the Soft-Skill Gap from Education to Employment through Internships. ProQuest LLC, 1-24.

Wong, M. M., Lau, K. H., \& Chan, C. (2020). How students work from home in a summer internship during Covid-19. https://doi.org/10.13140/RG.2.2.23687.83360 